retained the ondopolygalacturonase. These proparations showed no polygalacturonase or polymethylgalacturonase activity (at $p \mathbf{H} 4 \cdot 7$ ), as assessed by the viscosity ${ }^{11}$ and roducing group mothods ${ }^{12}$, while a test for pectinesterase ${ }^{13}$ was also negative. The toxicity ${ }^{14}$ of the crude culture filtrate to potato and cucumber slices was retained in the fractions showing macerating activity, supporting earlier views on the probable identity of macerating and toxic factors ${ }^{4,15}$.

At present, we suggest the use of the term 'maceration factor' for this thermolabile active substance, in preference to 'protopectinase', sinee the latter torm implies an onzymic nature, which we have failed to demonstrate: indeed, the level of protein in actively macerating percolates from 'Ectoola'-collulose was bolow the limits of ostimation by two methods ${ }^{16,17}$. The retardation of the maceration factor behind the main endopolygalacturonase peak suggests that it may be a smaller molecule? ; there was also some evidence of adsorption effects between the maceration factor and endopolygalacturonase.

R. J. W. BYRDE

Long Ashton Research Station, A. H. Fieloning

University of Bristol.

${ }^{1}$ Valleau, W. D., J. Agric. Res., 5, 365 (1915).

${ }^{2}$ Menon, K. P. V., Ann. Bot., 48, 189 (1934). Cole, J. S., Ann. Bot. N.S., 20 , 15 (1956).

'Demain, A. L., and Phatf, II. J., Wallerstein Labs. Commun., 20, 119 (1957).

‘ Wood, R. K. S., Ann. Rev. Plant Physiol., 11, 299 (1960).

${ }^{5}$ MeClendon, J. H., and Somers, G. F., Amer. J. Bot., 47, 1 (1960)

${ }^{6}$ Naef-Roth, S. Gaümann, E., and Albersheim, P., Phytopath. Z., 40, 283 (1961)

${ }^{\circ}$ Porath, J., and Flodin, P., Nature, 183, 1657 (1959).

"Brown, W., Ann. Bot., 29, 313 (1915).

- Dingle, J., Reid, w. W., and Solumons, G. L., J. Sci. Food Agric., 4, 149 (1953).

${ }^{10}$ Petergon, E. A., and sober, H. A., J. Amer. Chem. Soc., 78, 751 (1956)

11 Wood, R. K. S., Ann. Bot., N.8., 19, 1 (1955).

12 Jansen, E. F, and MacDonnell, L. R., Arch. Biochem., 8, 97 (1945).

13 Smith, W. K., J. Gen. Microbiol., 18, 33 (1958).

is Tribe, H. T., Ann. Bot., N.S., 19, 951 1955),

15 Brown, W., Ann. App. Biol., 43, 325 (1955).

18 Warburg, O., and Christian, W., Biochem. Z., 310, 384 (1941) "Lowry, O. H., Roscbrough, N. J., Farr, A. L., and Randall, R. J.,

\section{Plausibility of the Ribonucleic Acid Code}

RECENT experimental results indicate that there is a correspondence between RNA trinueleotides and amino-acids. Specifically, for each of the 20 aminoacids, published data list at least one trinucleotide believed to incorporate it in the protein synthesis machinery of $E$. coli. Surprisingly, in each of these published code-words, the symbol U (uracil) occurs in at least one of the three positions.

A careful examination of the exporimontal procedures reveals that 'random' polynucleotide chains could only be tested if they contained a strong preponderance (at least 65-70 per cent) of the symbol U. Specifically, the trinucleotides containing no $U$ were so much less probable than those containing $U$ that even if some of these were good code-words, and consistently incorporated their specific amino-acids, the frequency of thoso acids would have beon below the significance-level of the experiment. Other experimonts have suggested that a very few $U$-free triplets, such as AAA and CCC, do not code for any aminoacid.

In the face of these results, it is natural to inquire: Is it not overwhelmingly probable that $U$ is needed in most or all of the code-words? An affirmative answer to this question appears to be at variance with the fact that $U$ is not nearly so preponderant in Nature as this would seem to imply.

One hypothesis might be that the 37 triplets containing $U$ include the arnino-acid code-words, while the other 27 triplets include the regulatory instructions for the genetic process. However, the facts so far are also consistent with the following model.

Suppose that each amino-acid is 'randomly' assigned three different trinucleotides which code for it. Thus 60 of the 64 triplets are used as code-words. If only 37 of tho 64 triplets are 'observablo', how many different amino-acids should be represented among the observable triplets?

For a familiar probabilistic formulation one may imagine a pack of 64 cards, including four 'jokers' and three each of the numbers 1-20. If 37 cards are selected at random, how many differont numbers are expected to appear? In particular, how likely is it that all 20 numbers be represented at least once each ?

The formula for the probability of exactly $n$ different numbers in a hand of 37 eards from this pack of 64 is:

$$
\begin{array}{r}
P_{n}=\left(\begin{array}{c}
20 \\
n
\end{array}\right) \sum_{j=0}^{n-11}(-1)^{j}\left(\begin{array}{c}
n \\
j
\end{array}\right)\left(\begin{array}{c}
3(n-j)+4 \\
37
\end{array}\right) /\left(\begin{array}{l}
64 \\
37
\end{array}\right) \\
\text { for } 11 \leqslant n \leqslant 20
\end{array}
$$

Clearly $P_{n}=0$ for $n<11$ or $n>20$.

To an accuracy of \pm 0.002 , this leads to the data in Table 1 .

$\begin{array}{ccc} & \text { Table } 1 & \\ n & & P_{n} \\ 20 & & 0 \cdot 174 \\ 19 & & 0 \cdot 390 \\ 18 & & 0 \cdot 310 \\ 17 & & 0 \cdot 108 \\ 16 & & 0 \cdot 017 \\ 15 & & 0 \cdot 001 \\ 14 & & 0 \cdot 000\end{array}$

Thus, the odds of at least 19 distinct amino-acids being represented in a sample of 37 trinucleotides is better than an even bet; and the probability of at least 17 is a remarkable 98 per cent. The expectation of the distribution is 18.6 distinct amino-acids.

The principal conclusion from this calculation is that it is premature to reach firm conclusions about the role of the U-free trinucleotides.

California Institute of Technology, S. W. GoLOMB Pasadena.

\section{Deoxyribonucleic Acid Synthesis or Turn-over in Non-dividing Pollen Cells of Pine}

INVESTIGATIONS of deoxyribonucleic acid (DNA) formation in vivo have shown that synthesis and replication are completed before separation of chromosomes begins. DNA synthesis, as measured by staining, incorporation of phosphorus-32, or radioactive nucleotide precursors, has generally been thought not to occur in cells unless thoy aro proparing to divide ${ }^{1}$. Resenrch leading to such conclusions has usod developing angiosperm pollen cells (microspores) of Lilium ${ }^{2}$ and Tradescantia ${ }^{3}$ or bacteria and animal tissues.

Other investigations with bacteria ${ }^{5}$, nematodes, and animal tissues ${ }^{6}$ have indicated that synthesis or turnover of DNA may oceur in non-dividing eolls. This 